\title{
Allogeneic Irradiated Melanoma Cell Vaccine CSF470
}

National Cancer Institute

\section{Source}

National Cancer Institute. Allogeneic Irradiated Melanoma Cell Vaccine CSF470. NCI

Thesaurus. Code C103862.

An allogeneic cancer vaccine composed of a mixture of lethally irradiated whole melanoma cancer cells obtained from four different melanoma cell lines, with potential immunostimulating and antineoplastic activities. Upon intradermal injections, allogeneic irradiated melanoma cell vaccine may stimulate the body's immune system to exert a cytotoxic T-lymphocyte response and antibody-dependent cellular cytotoxicity (ADCC) against the melanoma cancer cells. 